\title{
Migration of businesses in the case of the
}

\section{Morvian-Seleian Region}

\section{Pavel Kukuliač}

\author{
Technical University of Ostrava, Institute of Geoinformatics, Faculty of Mining and Geology, The Czech Republic
}

This article deals with the assessment of the status and development of the distribution of economic activities in the Moravian-Silesian Region (MSR) in 1999-2009. The aim of this paper is to research the development of the geographical distribution of economic activities in relation to migration processes of these activities. In the case of this study, we focus on the monitoring of changes, particularly in the manufacturing industry, which is currently undergoing a process of deindustrialization. Migratory population movements are very important objects of interest for demographers. In fact, it is, together with the natural movement of the population (births, deaths), a key variable used for the description and prediction of demographic structures. These demographic indicators can be easily applied to monitor the development of economic activities in terms of their establishment, extinction, and movement in the study area.

Key words: migration, localization, economic sector, deindustrialization.

\section{Introduction}

The settlement structure of the Moravian-Silesian Region has recently been undergoing a marked transformation which is caused by several factors. The mechanisms of this process led to a transformation of the social structures of society as they have been known up to now. There has been a decline in the traditional areas of the economy and the traditional professions which are closely interconnected with city spaces - this is primarily true of industrial cities. At the same time, relatively deep in commensurabilities related to property have emerged, power or social position and these also exert their influence over the spatial structure of settlement. The agents of regional development do not have close ties to the territory any longer as the headquarters of their corporations are situated outside of the region. Processes of globalization therefore diminish the ability of public administration to regulate processes in the administered territory and this results in higher pressure on the management of municipalities when planning future development of the territory and its sustainability. The distribution of economic activities across city space has been changing and so has their structure. The paper focuses on the economic structure of the Moravian-Silesian region and especially on the migration of economic activities which have also been changing due to the process of deindustrialization.

Every business, whether large or small, goes through certain stages of development during its existence. This is called a life cycle of a company whose phases are according to Srpova et al. (2010) the following: the establishment, growth, stabilization, crisis and extinction. Localization theories deal with migration of existing businesses, but also emerging businesses. In the process of establishing companies, those companies can carry information about the process of selection of a suitable location for their business (Mariott, 2005). The newly established companies, however, have less information value on how and where businesses choose their place in space. Most often the choice of location is related to the location of housing, which is particularly true for small businesses (i.e., entrepreneurs). Choosing a suitable location for business is particularly important for existing businesses that often face the problem of placing a secondary production in another place.

A company that successfully survives the initial phase of its existence enters the growth phase. It has built a more or less solid position in its industry or region and begins to expand its scope (i.e., expand their business), be it 
territorially, product-wise or volume-wise (Srpova et al., 2010). Site selection becomes a very important factor for survival during the territorial expansion phase. Businesses have to constantly react and adapt to new situations and environmental influences. Migration or relocation may be considered as a form of adaptation. It may be a way to adapt to environmental changes, changes in local labour supply that affect the company's actual production or the organizational structure of the company (Pellenbarg, 2005). Studies on this topic have begun to appear in the postwar period, especially in the 1960s and 1970s. Among the most important studies in this area is the work of McLauhlin and Robock entitled "Why Industry Moves South". In this work, the authors observed the shift of companies from the northern to the southern states of USA. The main reasons for this shift were low salaries and the state of the labour market. During studies of the migration in Europe, it was found that de-concentration processes were occurring in the past. At the present the development is very uneven. First, it was the industry and then the service sector in the 1970s. The changing spatial structure of companies has an impact on the change of cities and their recovery (especially in the past). This change is associated with a spatial pressure resulting in, for example, congestion in cities and eventually the loss of function of employment of the city. The main motives for migration on the labour market, which include the lack of space and poor accessibility (Pellenbarg, 2005), are related to this.

This study can be applied and used in spatial planning since the development and distribution of human activities is crucial for planning and locating new activities. The aim of this work is to find certain patterns in the migratory behaviour of companies, both in terms of time and in terms of space. This can be useful for simulating and predicting the future development of the economy, searching for optimal distribution scenarios of economic activities and employment in the area, the possibility of simulating the impact of policy decisions which would affect national and local level investment activities (e.g. decision-making on construction of industrial zones and targeted support of activities in selected areas). Case studies similar to the undertaken one are resulting in better understanding of the spatial aspects and relationships of economic activities.

This article is organized as follows: the next section provides an overview of data which were used to assess the spatial distribution of economic activities. The third section describes the structure of industry in the MoravianSilesian region. The fourth section is devoted to the migration of companies within the study area. In the last chapter the results are presented.

\section{Data}

According to Tousek, Kunc, Vystoupil et al. (2008) the main problem of industry evaluation is the lack of up-to-date and accurate data, which does not allow more detailed spatial evaluation industry, especially at lower spatial levels. The following data were used for this work: data from the "Albertina data - Corporate Monitor" database, data from the Labour Office from various districts of the region, and data from the Czech Statistical Office (CSO). These data sources complement each other and provide the possibility to process a detailed analysis of the migration and distribution of economic activities in the region.

Albertina - Company Monitor (AFM) is a complex of interrelated and complementary databases on information about companies (AFM, 2009). The company indicates that updating is carried out on the basis of acquisition of information disclosed in Czech registers. Part of the data is continually updated, but especially for smaller companies the data are often not up-to-date. The content is very similar to the Register of Economic Entities.

Each half of the year the labour offices process employment data from the major employers in the district. The collection of the necessary data is realized via questionnaires which are sent out to individual employers. Employers can also send data about the company using a form that is placed on a separate web page of the labour office (Portal MPSV, 2010).

Register of Enumeration Districts and Buildings (REDB) is a hierarchical system of registered objects. It tracks objects' interrelations and changes in content, time and space (REDB ČSÚ, 2009). REDB is a database and geographic model 
of administrative, technical, settlement and statistical structure of the state. For this work, the essential attributes are the coordinates of the buildings (attributes JTSK_X JTSK_Y). Using the information on the exact address of the building and address of the company, it was possible to localize the companies in space. The data were joined using Microsoft Access.

\section{Structure of the Industry in the Moravian-Silesian Region}

The Moravian-Silesian region is situated in the north-eastern part of the Czech Republic. It neighbours Poland in the northeast and Slovakia in the southeast. The city of Ostrava is the administrative, economic and cultural centre of the region. The largest cities in the Moravian-Silesian region are Ostrava, Opava, Frýdek-Místek, Karviná, Nový Jičín and Bruntál. The Moravian-Silesian region became the country's most important industrial centre during the last century and it still holds this position. The centre of this industrial area is the agglomeration called OstravskoKarvinska. The expansion of industrial development of this area is connected to the utilization of the area's mineral wealth and to the development of rail transportation. Nowadays this industrial area is being restructured with the aim of extending industrial activities and revitalizing all kinds of services. Other important sectors include chemicals and pharmaceuticals, electrical engineering, textiles industries, paper production and food processing.

At the present time, the Moravian-Silesian Region accounts for $12.4 \%$ in the population of the Czech Republic. Considering the age structure, it has the highest number of inhabitants in the Czech Republic and in the region in the productive age, approx. $70-71 \%$. The rate of economic activity of population in the Moravian-Silesian Region (MSR) has got a decreasing tendency like the whole number of population but also according to the structure by gender.

The Ostrava region is one of the most industrialised parts of the Czech Republic with extensive mining, metallurgy, steel and oil processing and heavy engineering activities. Many foreign investors have already set up their production facilities in the region and take advantage of skilled labour force. The region suffered from heavy pollution in the past but extensive cleanup programs in recent years have improved the environment significantly. Besides the heavy industry, sectors such as pharmaceutical industry, food processing, production of building materials or automotive have been steadily developing. Restructuring in traditional industries has been shifting the region 's industrial base to light manufacturing - automotive, metalworking and electrical engineering. The Business and Innovation Centre and the Science and Technology Park in Ostrava were set up to keep the new industries growing. 


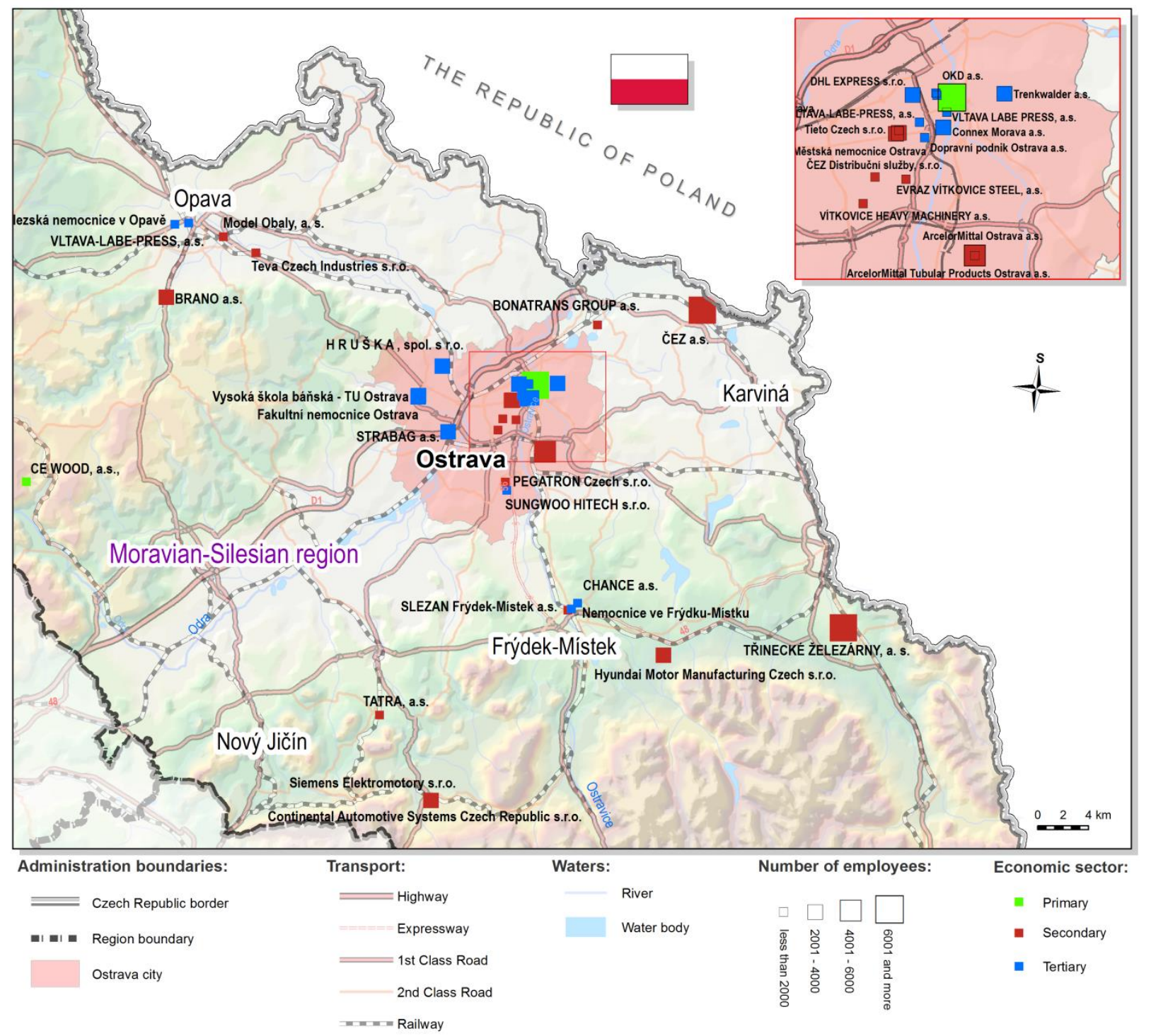

Figure: 1 Distribution of major companies in the Moravian-Silesian region in 2009

Data source: ČSÚ, ŘSD 2010, ÚP Ostrava, AFM 2009. Note: Institute of Geoinformatics Technical university of Ostrava, Administration boundaries valid as of 1.7.2010, Coordinate system S-JTSK.

Ostrava - the third largest city in the Czech Republic - is the business, educational and cultural centre not only for the region but for the whole north eastern Czech Republic. Ostrava and other adjacent towns constitute a metropolitan area with a population of over 500,000 inhabitants. As of 31.12. 2009, there were over 240,000 registered businesses in the MSR according to the CSO (2009). 3 percent of these businesses were in agriculture, forestry and fisheries, and over 12 percent in industry. The rest was attributable to other sectors such as trade and servicing of motor vehicles, accommodation, education, cultural activities, etc. 68,083 subjects were registered in the sectors of retail and wholesale of motor vehicles. In the region, there are currently 30,535 industrial businesses, with a vast majority belonging to the manufacturing industry. The largest share of agricultural entities in the region is located in Bruntál and Opava districts. Mining activity is concentrated in the area of Karviná.

Two-thirds of the registered entities in the research and development fields are concentrated in Ostrava. The same is true for entities in human resources management. Nearly a half of all entities involved in the manufacturing of computers, electronics and optical devices are also located in Ostrava. If we focus only on the most important companies in the region (with 1,000 or more employees), a significant concentration can be seen particularly in Ostrava and also in other large cities such as Opava, Frýdek-Místek and Karviná (Figure 1). The Nošovice industrial zone, where companies focus particularly on the automotive industry, is also important.

In tab. 1 the number of companies for each period is listed. An increasing trend in the number of businesses can be seen since 1998. It can also be observed that the number of businesses was reduced in some districts between 2004 
and 2006. The Czech statistical office performed an evaluation of the number of emerging and vanishing companies in 2000-2005, and one possible explanation for this phenomenon is the fact that in 2004 there was a legislative amendment to the changing conditions of advance payments of entrepreneurs and overall tightening of business records. There was also a tax adjustment, which introduced a so-called minimum tax, and the mandatory contributions to social security and health insurance were increased. As a result, many entrepreneurs asked for a status change of their businesses, which in turn meant an interruption or a demise of their activities.

Tab.: 1 Number of businesses in the districts of the MSR in $1998-2009$

\begin{tabular}{|l|r|r|r|r|r|r|}
\hline District & \multicolumn{1}{|c|}{$\mathbf{1 9 9 8}$} & \multicolumn{1}{|c|}{$\mathbf{1 9 9 9}$} & \multicolumn{1}{c|}{$\mathbf{2 0 0 4}$} & \multicolumn{1}{c|}{$\mathbf{2 0 0 6}$} & $\mathbf{2 0 0 8}$ & $\mathbf{2 0 0 9}$ \\
\hline Ostrava - město & 48468 & 54634 & 69079 & 67491 & 70872 & 74821 \\
\hline Bruntál & 13574 & 15428 & 18011 & 18155 & 19354 & 20385 \\
\hline Karviná & 29131 & 32145 & 36349 & 37874 & 38406 & 41633 \\
\hline Frýdek - Místek & 25334 & 28412 & 37194 & 36387 & 37927 & 40676 \\
\hline Opava & 21484 & 25611 & 32821 & 32731 & 33936 & 36231 \\
\hline Nový Jičín & 19350 & 21825 & 26847 & 27197 & 28458 & 29556 \\
\hline Number of businesses & $\mathbf{1 5 7 3 4 1}$ & $\mathbf{1 7 8 2 4 6}$ & $\mathbf{2 2 0 3 0 1}$ & $\mathbf{2 1 9 8 3 5}$ & $\mathbf{2 2 8 9 5 3}$ & $\mathbf{2 4 3 3 0 2}$ \\
\hline
\end{tabular}

Data source: AFM a.s.

Note: own processing

\section{Migration of Businesses}

In this section, an assessment of migration of business headquarters in the Moravian-Silesian Region is made. Visualisation of migration flows of companies is carried out using proportional symbols. Migration is evaluated for years 1999-2009. The analysis is based on the existence of a unique ID number of each company, as well as the fact that the company belongs to the chosen locality. If the enterprise exists in both years, and also belongs to the given area, it is possible to determine whether the company migrated or not. The analysis includes companies that have existed since 1999 and have maintained their existence until 2009. Businesses that emerged after 1999 or before 2009 came to an end were not included in the analysis.

The aim of the analysis was to determine to what extent and in what spatial structure the corporate headquarters in the Moravian-Silesian Region migrate. Proportional symbols, which are used in this analysis, graphically demonstrate the number of migrating companies between municipalities in the region. The number of emigrants is expressed by line width. For the sake of readability, only significant numbers of migrating companies are taken into account (30 or more companies). It is necessary to point out that the analysis is limited to migration within the MSR; therefore, migration outside the Moravian-Silesian Region is not taken into account.

In the monitored period of 1999-2009, 12,694 companies have moved to other municipality. More than half of the total number of monitored companies remained in the same municipality. In this period, 65,056 companies have been founded and 40,820 companies have been closed. According to CSO (2011) in 2000, the ratio between new and closed businesses was 3.7:1, in 2005 this ratio was 1.9:1. This trend in the formation and disappearance of companies continued to the present day.

Tab.: 2 Basic evaluation of migration in the MSR in 1999-2009

\begin{tabular}{|c|c|c|c|c|c|c|c|c|}
\hline & \multicolumn{2}{|c|}{ Unchanged position } & \multicolumn{2}{|c|}{$\begin{array}{l}\text { Relocated businesses } \\
\text { (among municipalities) }\end{array}$} & \multicolumn{2}{|c|}{$\begin{array}{c}\text { New } \\
\text { businesses }\end{array}$} & \multicolumn{2}{|c|}{$\begin{array}{l}\text { Businesses } \\
\text { closures }\end{array}$} \\
\hline & abs. & [\%] & abs. & [\%] & abs. & [\%] & abs. & [\%] \\
\hline 1999-2009 & 124732 & 51,3 & 12694 & 5,2 & 65056 & 26,7 & 40820 & 16,8 \\
\hline Number of businesses 1999 & & & & & & & \multicolumn{2}{|c|}{178246} \\
\hline Number of businesses 2009 & & & & & & & & 43302 \\
\hline
\end{tabular}




\begin{tabular}{|l|l|l|l|l|}
\hline & Unchanged position & $\begin{array}{l}\text { Relocated Business } \\
\text { (among municipalities) }\end{array}$ & New Businesses & Closure of Businesses \\
\hline $\mathbf{1 9 9 9 - 2 0 0 9}$ & $\mathbf{1 2 4 7 3 2}-\mathbf{5 1 . 3} \%$ & $12694-5.2 \%$ & $65056-26.7 \%$ & $40820-16.8 \%$ \\
\hline & Row 2 heading & Data & & Data \\
\hline
\end{tabular}

\section{Number of businesses 1999: 178246 \\ Number of businesses 2009: 243302}

Data source: AFM a.s.

Note: own processing

The spatial structure of migration in the territory of MSR is shown in the map in Figure 2. It can be easily seen that the towns near the city of Ostrava acquired businesses while the city itself lost them. This is a symptom of a process of suburbanization which is apparent in all other major cities in the region. A similar trend can be observed in cities in the areas of Karviná (Karviná, Orlova, Havířov and Bohumín) Novojičínsko (Bílovec, Studénka, Příbor, Odry, New Jičín), followed by Frýdek-Místek (Frýdek-Místek), Opava (Opava, Vítkov) and Bruntál (Bruntál, Krnov, Rýmařov, Vrbno pod Pradědem) (Tvrdý et. al., 2011). All these major cities in the MSR companies lose companies, especially if they are small businesses. This fact is exhibited by the 11,000 entrepreneurs who moved during this period. This number represents 85 percent of all businesses for which there has been a change in the location within the municipalities of the MSR. The structure of the migration of business is so significantly affected by population movement itself, because in the case of self-employed entrepreneurs, their business is closely linked with the place of their permanent residence. These people usually move out of the city, especially to suburban areas which causes a subsequent increase in the number of entrepreneurs in these areas. 


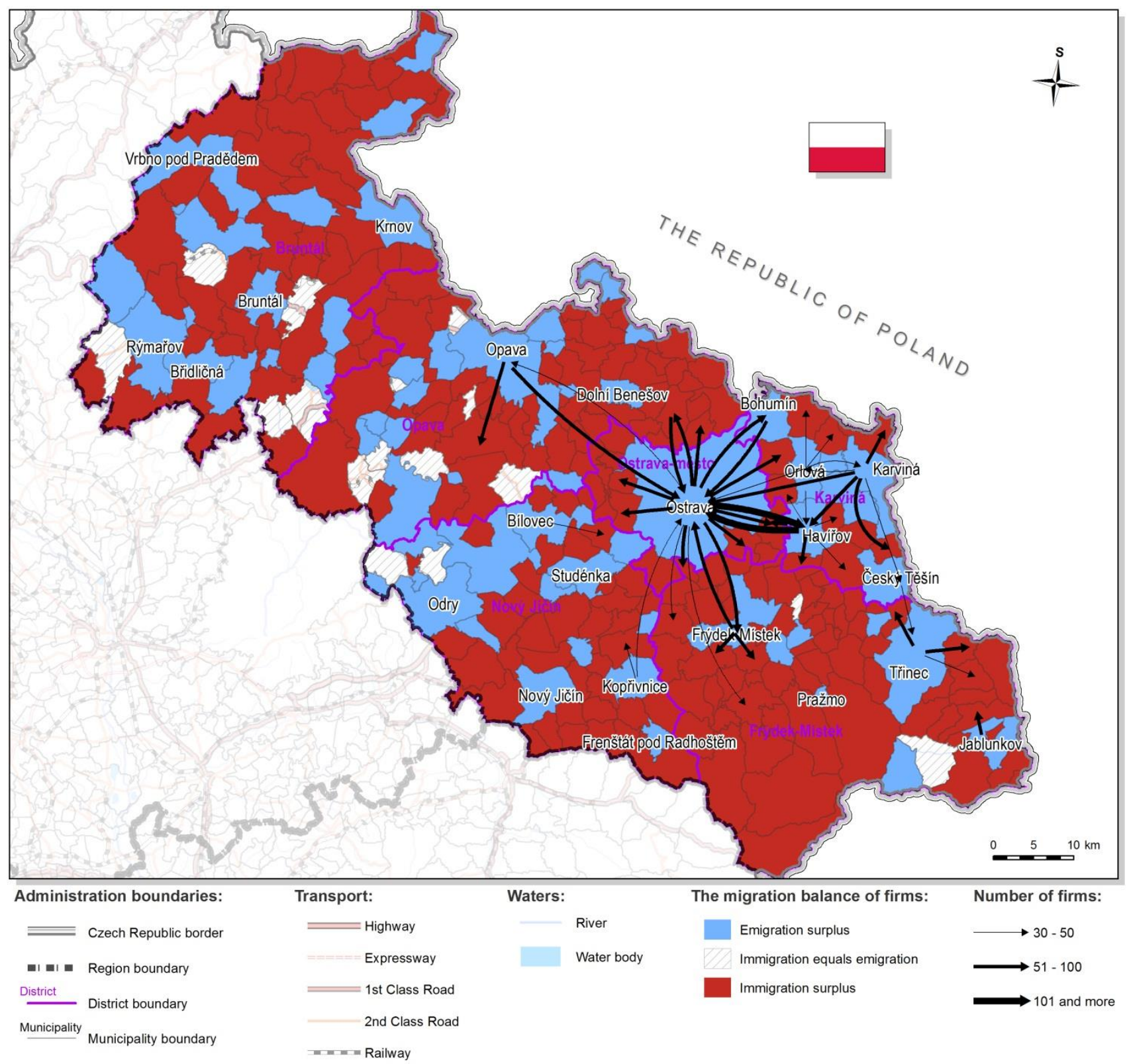

Figure: 2 Migration balance and significant migration flows in the MSR in 1999 - 2009

Data source: ČSÚ, ŘSD 2010, AFM 2009.

Note: Institute of Geoinformatics Technical university of Ostrava, Administration boundaries valid as of 1.7.2010, Coordinate system S-JTSK.

The most important migration flows occur in the four largest cities in the region: Ostrava, Havírov, Frýdek-Místek and Opava (figure 2). These are all cities more than 50,000 inhabitants. According to the Czech Statistical Office (2010), Ostrava is the most dominant city having 306,006 inhabitants in 2009. The strongest migratory movements can be observed between Ostrava and Havírov. Havířov is often referred to as a suburb of Ostrava. During the study period, 231 businesses moved from Haviŕov to Ostrava, while only 116 businesses moved in the opposite direction. The conclusion is that Ostrava is more attractive for entrepreneurs than Havírov. The reality is that people from Haviŕov commute to Ostrava for work and entertainment, and due to Haviŕov's spatial proximity and good transport links to Ostrava, it is becoming a place suitable especially for housing. A similar trend can also be observed between Ostrava and Opava, where the number of businesses migrating to Ostrava was twice as big as the number of those emigrating from Ostrava to Opava.

In terms of economic specialization, a significant migration of businesses within the following industries was found: retail trade, vehicle repair services, and personal and household goods. These industries belong to the tertiary sector. Generally oriented businesses in the service sector are the most affected. Of the total number of monitored 
companies, 82 percent of them belonged to the services sector, 11 percent belonged to the manufacturing sector and only 5 percent belonged to the primary sector, which is focused on agriculture, fishing and mining activities.

Tab.: 3 Migration of businesses in the districts of the MSR in 1999-2009

\begin{tabular}{|l|r|l|r|r|r|r|r|}
\hline District & Bruntál & $\begin{array}{l}\text { Frýdek- } \\
\text { Místek }\end{array}$ & Karviná & Nový Jičín & Opava & $\begin{array}{l}\text { Ostrava- } \\
\text { město }\end{array}$ & $\begin{array}{l}\text { Total number } \\
\text { of emigrants }\end{array}$ \\
\hline Bruntál & $\mathbf{8 0 0}$ & 10 & 27 & 15 & 85 & 91 & 1028 \\
\hline Frýdek-Místek & 15 & $\mathbf{2 1 1 1}$ & 401 & 91 & 32 & 617 & 3267 \\
\hline Karviná & 21 & 163 & $\mathbf{1 7 3 1}$ & 22 & 28 & 385 & 2350 \\
\hline Nový Jičín & 12 & 58 & 35 & $\mathbf{1 2 0 2}$ & 51 & 252 & 1610 \\
\hline Opava & 67 & 27 & 59 & 40 & $\mathbf{1 3 9 1}$ & 537 & 2121 \\
\hline Ostrava-město & $\mathbf{7 4}$ & 279 & 628 & 339 & 426 & $\mathbf{5 7 2}$ & 2318 \\
\hline $\begin{array}{l}\text { Total number } \\
\text { of immigrants }\end{array}$ & $\mathbf{9 8 9}$ & $\mathbf{2 6 4 8}$ & $\mathbf{2 8 8 1}$ & $\mathbf{1 7 0 9}$ & $\mathbf{2 0 1 3}$ & $\mathbf{2 4 5 4}$ & $\mathbf{1 2 6 9 4}$ \\
\hline
\end{tabular}

Data source: AFM a.s.

Note: own processing

Migration of businesses in the MSR has been occurring mainly within districts, as evidenced by the results of the analysis shown in table 3. Sixty-two percent of businesses have changed their location within the districts' border, and the remaining 38 percent have moved to other districts in the MSR. The largest migration movements occurred in the district of Frýdek-Místek. Frýdek-Místek is one of the largest districts in the region. Therefore, the increased migration within this district might be a result of poorly chosen administrative boundaries. On the other hand, the largest city of this district is one of the three most important cities in terms of employment, population and concentration of economic subjects in the region. Bruntál, Frýdek-Místek and Opava were losing their businesses; by contrast, districts of Karviná, Nový Jičín and Ostrava city were gaining new businesses. In these areas there are significant industries such as ArcelorMittal, Vítkovice, Tatra, Bonatrans Group, ČEZ and many others. These businesses attract entrepreneurs from other parts of the MSR, who tend to cooperate with these large companies and thus benefit from their proximity.

\section{Conclusion}

Migration of companies along with their formation, expansion, decline or closure has a significant impact on their distribution in space. In the literature we can find three main categories influencing corporate migration: internal factors (such as company size by number of employees or their economic performance, cost savings), external factors (e.g. market size) and localization factors (e.g. raw materials, climate conditions) (Pellenbarg, 2005).

It was found that the migration of businesses decreases with their size. In terms of detailed data analysis it is possible to say that the migration is proportional to the age of the business. Large and stable businesses that operate in the MSR for a long time do not need to migrate. This is due mainly to their localization in the vicinity of mineral resources and access to local markets (Mariotti, 2005). The most significant migratory behaviour was observed in the service sector. This sector consists mainly of small businesses (i.e., entrepreneurs), whose registered office is associated with their place of residence. Migration of these entrepreneurs is then shaped by migration of the population; the tendency is to move to suburban areas. This leads to the loss of businesses in all the major cities of the Moravian-Silesian Region. The largest decrease was observed in the municipalities of Ostrava, Havírov, Karviná and Opava. Migration in the territory of the Moravian-Silesian region can be characterized as a local migration structure, since most migrant businesses changed their office only in their district.

Works of this type are particularly important in the field of regional policy and spatial planning. The aim of this study was to provide knowledge that could be generalized for other cities in the country. The problem of this analysis was to set a good limit of the area in which migration was investigated. It would be better in this respect to analyze the migration of companies beyond the Moravian-Silesian region and across the state borders. The Moravian-Silesian 
region, and especially the Ostrava agglomeration, is potentially the best integrated cross-border space in the Czech Republic. It is a heavily populated area, which includes the Polish cities of Katowice, Rybnik and Wodzislaw Slaski. The problem is the unavailability of usable data.

AFM. Albertina data s.r.o. Firemní monitor. 2009. [online]. Available at:

http://www.albertina.cz/base.php?lang=cz\&page=afm [Accessed 20 November 2009].

Čsú, 2010. Český statistický úřad: Definice RSO. [online] Available at:

http://www.czso.cz/csu/rso.nsf/i/definice registru [Accessed 10 October 2009].

Dijk, J., Pellenbarg, P.H., 1999. Demography of firms: Spatial Dynamics of Firm Behaviour. Groningen: Koninklijk Nederlands Aardrijkskundig Genootschap.

Hruška-Tvrdý, L., Kukuliač, P., Foldynová, I., Horák, J., Ivan, I., 2011. Socioeconomic atlas of Ostrava. Ostrava: ACCENDO- Centrum pro vědu a výzkum, o.p.s.

Hruška-Tvrdý, L., Illner, M., Musil, J., Keller, J., Kovář, J., Šotkovský, I., Ivan, I., 2010. Industriální město v postindustriální společnosti. Ostrava: Vysoká škola báňská-Technická univerzita Ostrava.

Mariotti, I., 2005. Firm relocation and regional policy. A focus on Italy, the Netherlands and the United Kingdom. Groningen: Department of Spatial Sciences, University of Groningen.

Pellenbarg, P.H., Van Steen, P.J.M., 2003. Spatial Perspectives On Firm Dynamics In The Netherlands. Journal of Economic and Social Geography. 94(5), pp. 620-630.

Pellenbarg, P.H., Van Steen, P. J.M., 2003. The demography of firms in the Netherlands: introduction to the 2003 maps. Journal of Economic and Social Geography. 94(1), pp.144-146.

Pellenbarg, P.H., 2005. Firm migration in the Netherlands. [pdf] Amsterdam: ERSA congress. [online] Available at: http://www-sre.wu-wien.ac.at/ersa/ersaconfs/ersa05/papers/435.pdf [Accessed August 2005].

Srpová, J., Řehoř, V., 2010. Základy podnikání: Teoretické poznatky, príklady a zkušenosti českých podnikatelů. Praha: Grada Publishing.

Synek, M., 2002. Podniková ekonomika. Third edition. Praha: C.H. Beck.

Toušek, V., Kunc, J., Vystoupil, J., 2008. Ekonomická a sociální geografie. Plzeň: Aleš Čeněk, s.r.o.

Tvrdý, L., Ivan, I., Foldynová, I., 2009. Trh práce a krize v Moravskoslezském kraji. [pdf] Ostrava. [online] Available at: http://gisak.vsb.cz/ iva026/source/2009 MSK trh prace a krize.pdf [Accessed June 2009].

Van Wissen, L. J.G., 2002. Demography of the Firm: A Useful Metaphor? European Journal of Population. 18(3), pp. 263-279.

\section{Acknowledgements}

I want to thank all the enthusiastic and helpful people who in one way or another helped me during my Masters project. I am grateful to Jan Lojek for the translation of this paper.

\section{Biography}

Pavel Kukuliač was born in the Czech Republic. He received his Bachelor of Science in Geoinformatics in 2009 and Master of Science in Geoinformatics in 2011, both from Institute of Geoinformatics in the Technical university of Ostrava in the Czech Republic. Presently, he is studying PhD programme. He is interested in a spatial analysis especially in spatial distribution of economic activities. This paper was created during his study internship at the UCC (September 2012 - February 2013) . 